\title{
CAUSES OF HEARING AID REJECTION IN GERIATRIC POPULATION OF EGYPTIAN RURAL AREAS
}

\author{
Ola Abdallah Ibraheem M.D. \\ Audio-vestibular Medicine, Audio-vestibular Unit, Otorhinolaryngology Department, Faculty of \\ Medicine, Zagazig University, Egypt
}

\author{
Corresponding author \\ Ola Abdallah Ibraheem \\ Address: Audio-vestibular \\ Unit, Otorhinolaryngology \\ Department, Faculty of \\ Medicine, Zagazig \\ University, Egypt \\ Telephone: +201001301978 \\ E-Mail: \\ ola_medvoice@yahoo.com
}

\begin{abstract}
Background: Hearing loss affects a considerable proportion of geriatrics in Egypt. Although hearing aid technology is improving, there is still a high prevalence of hearing aid rejection in elder population. Causes of hearing aid rejection in rural geriatric population were not investigated in previous researches. Objective: This study aimed to detect causes of hearing aid rejection in rural geriatric population. Patients and Methods: Thirty rural elders of both genders, $\geq 65$ years old, with $\geq$ moderately severe hearing loss participated in this study. They were subjected to history taking, Hearing Handicap Inventory for the elderly, queries about causes of $\mathrm{HA}$ rejection in rural areas, and basic audiological evaluation. Results: Psychosocial causes of hearing aid rejection were the more prevalent $(36.7 \%)$, followed by audiological $(20 \%)$, cultural believes $(16.7 \%)$, device, and organic causes. Factors such as age, education, self-perceived disability, type and degree of hearing loss, and speech intelligibility affect the prevalence of theses causes. Conclusion: Identifying causes of hearing aid rejection and factors influencing them helps proper modification of hearing rehabilitation strategies.

Keywords: geriatrics; hearing aid rejection; hearing loss; rural areas.

Abbreviations: HL: hearing loss; HA: hearing aid; HHIE-S: Hearing Handicap Inventory for the Elderly (screening version); LSD: least significant difference; PTA: pure tone average; SD: standard deviation; SNHL: sensorineural hearing loss; SRTs: speech reception thresholds; SRSs: speech recognition scores; $\mathrm{X}^{2}$ : Chi-square.
\end{abstract}

\section{INTRODUCTION}

$\mathbf{H}$ earing loss (HL) in geriatrics is highly prevalent, affecting more than one-third of subjects aged 65 years or more ${ }^{[1]}$. It exists in $30 \%$ of the age range 65 to less than 75 years and in $40 \%-60 \%$ of the ages equal to or more than- 75 years ${ }^{[2]}$. In Egypt, elder population ( $\geq 65$ years) was reported to have the highest prevalence (49.3\%) as compared to younger ages ${ }^{[3]}$. Many studies supported the association between HL and physical, social, cognitive, and psychological disturbances ${ }^{[4,5]}$.

Proper amplification with a suitable hearing aid (HA) provides a good solution for the age-related HL with subsequent improvement in communication, quality of life, social impairment, and psychological insults ${ }^{[6,7]}$. Despite the evolving HA technology, a relatively small proportion of hearing-impaired elders (10 to 30\%) own HA and $24 \%$ of the HA holders do not wear it $[4,6,8]$.
Factors imply HA rejection exceed the improper HA to include audiological, psychological, cognitive, financial, tolerance, social, and demographic factors ${ }^{[9,10]}$. In rural areas, there are growing proportions of elder people ${ }^{[11]}$. Thus, it is expected for the prevalence of HA rejection to increase owing to the limited self-motivation, general health impairments compared with younger ages, limited educational and community services, costs, and difficulties in attracting staff.

Previous researches concerned with the HA administration in elders, did not consider rural areas ${ }^{[6,12]}$. This study aims to estimate the underlying factors of HA rejection among elder subjects living in rural areas. Highlighting these challenges could improve the intervention techniques that increase HA acceptance and usage.

\section{Participants}

\section{SUBJECTS AND METHODS}

This retrospective study included 30 hearing impaired elders coming from rural 
areas of El-Sharkia governorate. Rural areas are referred to as regions that are geographically placed outside cities [13]. Participation in the study followed an announcement for those who possessed HAs but did not use them to explore the underlying problem. Subjects with age $\geq 65$ years and more than moderate degree of HL were involved in this study. Those with mild and moderate degrees of HL found enough hearing without HA. Thus, they did not wish to have one. The HAs were of digital type with at least wide dynamic range compression method. They were fitted following audiological evaluation and fine-tuning. Subjects were irregularly using their HAs prior to the rejection. Investigations were performed in Audiology Unit, ORL Department, Zagazig University, Egypt, after obtaining a written consent from each participant after an approval from the institutional ethical committee. The time spam for this work extended from July 2016 to January 2017.

\section{Equipment}

- Two channel audiometer Madsen (Orbiter 922 version 2, Hauppauge, USA) calibrated depending on ANSI 1969. The air conducted stimulus was conveyed using supra aural headphone model TDH (49) or in free field using loudspeakers

- Sound treated room locally made.

- Immittancemeter Madsen (model Zodiak 901, USA).

\section{Procedures}

The evaluation started with a comprehensive history taking including demographic, socioeconomic, and educational data. Subjects were divided into two groups based on the education: educated group including 18 subject $(60 \%)$ and illiterate group including 12 subjects $(40 \%)$. The impact of HL on emotional and social aspects was assessed through administration of the Arabic translated Hearing Handicap Inventory for the Elderly (version of screening) (HHIES) (Appendix 1) [14]. This ten-item questionnaire provides a score ranging from 0-40 that is subdivided as follow; 0-8 indicating no perceived handicap, 10-22 indicating mild to moderate handicap, and 2440 indicating severe handicap. According to the HHIE-S, subjects with scores $\leq 8$ were considered non-handicapped $(46.7 \%)$ while those with scores $>8$ were considered handicapped (53.3\%).

Possible causes of HA rejection in rural geriatric population were explored using queries recruited from a preliminary pilot study. This study involved direct enquiry about the main cause for HA rejection among the residents of rural areas. The queries were related to several factors including audiological, device, cultural believes, psychosocial, and organic factors and the answer was either yes or no. The Arabic form of these queries is presented in appendix (2):

1. Audiological factors:

- Poor speech recognition

- Uncomfortable listening (abnormal loudness growth, distortion, internal noise)

- Difficult listening in noisy situations

- $\quad$ Poor sound quality

2. Device related factors:

- Cost

- Maintenance

3. Cultural believes: (coexistence with the belief that hearing disability is a natural progress to old age and does not require intervention).

4. Psychosocial factors:

$\begin{array}{ll}\text { - } & \text { Stigma of HA usage } \\ \text { - } & \text { Disappointed with HA } \\ \text { - } & \text { Only used for limited situations } \\ \text { 5. } & \text { Organic factors: } \\ \text { - } & \text { Allergy } \\ \text { - } & \text { Infection }\end{array}$

Declining manual dexterities in old age did not included as in rural areas; elders have big families with all members live together and provide enough support. Moreover, elders who exhibited audiological causes, requested fine-tuning for few times prior to HA rejection.

Basic audiological evaluation was started with otoscopic examination to inspect the tympanic membrane. Then, middle ear functions were assessed via immittancemetery. Pure-tone audiometry was examined in the frequency range 250 $8000 \mathrm{~Hz}$ for air conduction and the frequency range $500-4000 \mathrm{~Hz}$ for bone conduction. The 
pure tone average (PTA) of hearing thresholds at $500-4000 \mathrm{~Hz}$ was calculated. The degrees of HL express the severity of HL that varies from mild to profound degrees ${ }^{[15]}$. This study involved the moderately severe (56-70 dB HL), severe (71-90 dB HL), and profound ( $>90 \mathrm{~dB}$ HL) degrees, in addition to the sensorineural (SNHL) and mixed types of HL. This is followed by speech audiometry involving speech reception thresholds (SRTs) and speech recognition scores (SRSs). Then, thresholds and SRSs were reevaluated in free field using the aided condition.

\section{Statistical analysis}

Analysis was implemented using SPSS software version 21. Descriptive analysis was used to calculate the mean \pm standard deviation (SD) and the frequency of variable sub-categories. Comparison between variables was performed using one way ANOVA and paired sample $t$ tests for numerical data and Chi-square $\left(\mathrm{X}^{2}\right)$ test for categorical data. The least significant difference test (LSD) was performed to detect the relationship between subcategories of the variables. Significant difference was reported if the $p$ value was less than 0.05 .

\section{RESULTS}

The mean age of geriatric subjects who rejected HA was $72.8 \pm 6.1$ years old with $56.7 \%$ males and $43.3 \%$ females. There were no significant difference in the distribution of males versus females, educated versus illiterate, and handicapped versus nonhandicapped (Table1). Table 2 shows the audiologic outcome of participants. A higher prevalence was found for the moderately severe $(46.7 \%)$ followed by the severe $(36.7 \%)$ then the profound $(16.6 \%)$ degrees of HL. However, this did not reach significance. On the other hand, significant differences were found between the PTA, aided free field response average, SRTs, SRSs, and aided SRSs of the three degrees of HL. Paired sample $t$ test revealed significant difference between PTA $(73.5 \pm 14.5)$ and aided free field response average $(24.3 \pm 8.5)(t=33.84$ and $p=$ 0.000 ) and significant difference between SRSs and aided SRSs for moderately severe $(t=6.000$ and $p=0.000)$ and severe $(t=4.183$ and $p=0.002)$ HL but not for profound HL ( $t=2.449$ and $\mathrm{p}=0.07$ ). Regarding types of HL, SNHL exhibited a significantly higher prevalence $(73.3 \%)$ as compared to mixed HL $(26.7 \%)$.

Causes of HA rejection included five factors; audiological, device related, cultural believes, psychosocial, and organic. Figure (1) represents the frequency of occurrence of each of these factors which did not differ significantly from each other $\left(X^{2}=5.667\right.$ and $p=0.225)$. The relationship between both demographic and audiologic characteristics and causes of HA rejection was revealed in table (3). Age was significantly older within audiological related subcategory relative to device related one (LSD: $p=0.03$ ). No specific relationship was found between gender and causes of HA rejection. Regarding the educational state, there were significant difference between educated and, illiterate for audiological factors, and cultural believes. Among the educated subjects, audiological factors were significantly higher, but the cultural believes were significantly higher among illiterates. Moreover, audiological factors were significantly higher in the handicapped relative to the non-handicapped while the organic factors were significantly higher in the non-handicapped relative to the handicapped. The profound HL was significantly associated with audilogical causes than did the moderately severe HL (figure 2), whereas the mixed type of $\mathrm{HL}$ exhibited significantly higher organic causes relative to the SNHL (figure 3). Significant differences of SRSs were noted among the different causes of HA rejection as shown in table (3). 
Table 1: Demographic characteristics of rural geriatrics.

\begin{tabular}{|c|c|c|c|c|}
\hline \multicolumn{3}{|c|}{ Characteristics } & Value & $p$ \\
\hline $\begin{array}{l}\text { Age } \\
\text { (years) }\end{array}$ & Mean \pm SD & $72.8 \pm 6.1$ & - & - \\
\hline \multirow[t]{2}{*}{ Gender } & Male: no (\%) & $17(56.7 \%)$ & \multirow[t]{2}{*}{$0.533^{\#}$} & \multirow[t]{2}{*}{0.465} \\
\hline & Female: no (\%) & $13(43.3 \%)$ & & \\
\hline \multirow[t]{2}{*}{ Education } & Educated: no (\%) & $18(60 \%)$ & \multirow[t]{2}{*}{$1.200^{\#}$} & \multirow[t]{2}{*}{0.273} \\
\hline & Illiterate: no (\%) & $12(40 \%)$ & & \\
\hline \multirow[t]{2}{*}{ HHIE-S } & Non-handicapped $(\leq 8)$ : no $(\%)$ & $14(46.7 \%)$ & \multirow[t]{2}{*}{$0.133^{\#}$} & \multirow[t]{2}{*}{0.715} \\
\hline & Handicapped (> 8): no (\%) & $16(53.3 \%)$ & & \\
\hline
\end{tabular}

$\#: \mathrm{X}^{2}$ value

Table 2: Audiologic prifile of rural geriatric population.

\begin{tabular}{|c|c|c|c|c|}
\hline \multicolumn{3}{|c|}{ Characteristics } & \multirow{4}{*}{$\frac{\text { Value }}{4.200^{\#}}$} & \multirow{2}{*}{$\begin{array}{ll}p \\
0.122\end{array}$} \\
\hline \multirow{3}{*}{$\begin{array}{l}\text { Frequency } \\
\text { of } \quad H L \\
\text { degrees }\end{array}$} & Moderately severe: no (\%) & $14(46.7 \%)$ & & \\
\hline & Severe: no (\%) & $11(36.7 \%)$ & & \\
\hline & Profound: no (\%) & $5(16.6 \%)$ & & \\
\hline \multirow{3}{*}{$\begin{array}{l}\text { Degrees of } \\
\mathrm{HL} \text { (PTA) } \\
{[\mathrm{dBHL}]}\end{array}$} & $\begin{array}{l}\text { Moderately severe: Mean } \pm \\
\text { SD }\end{array}$ & $60.1 \pm 3.5$ & \multirow[t]{3}{*}{$210.2^{\vee}$} & \multirow[t]{3}{*}{$0.000(a, b, c)^{*}$} \\
\hline & Severe: Mean \pm SD & $79.9 \pm 4.1$ & & \\
\hline & Profound: Mean \pm SD & $97 \pm 3$ & & \\
\hline \multirow{3}{*}{$\begin{array}{l}\text { Aided free } \\
\text { field } \\
\text { response } \\
\text { average } \\
{[\mathrm{dBHL}]}\end{array}$} & $\begin{array}{l}\text { Moderately severe: Mean } \pm \\
\text { SD }\end{array}$ & $17.9 \pm 2.6$ & \multirow[t]{3}{*}{$57.5^{\diamond}$} & \multirow[t]{3}{*}{$0.000(\mathrm{a}, \mathrm{b}, \mathrm{c})^{*}$} \\
\hline & Severe: Mean \pm SD & $25.9 \pm 4.9$ & & \\
\hline & Profound: Mean \pm SD & $39 \pm 4.2$ & & \\
\hline \multirow{2}{*}{ Type of HL } & SNHL: no (\%) & $22(73.3 \%)$ & \multirow[t]{2}{*}{$6.533^{\#}$} & \multirow[t]{2}{*}{0.011} \\
\hline & Mixed HL: no (\%) & $8(26.7 \%)$ & & \\
\hline \multirow[t]{3}{*}{$\begin{array}{l}\text { SRTs } \\
{[\mathrm{dBHL}]}\end{array}$} & $\begin{array}{l}\text { Moderately severe: Mean } \pm \\
\text { SD }\end{array}$ & $57.5 \pm 5.1$ & \multirow[t]{3}{*}{$102.7^{\diamond}$} & \multirow[t]{3}{*}{$0.000(\mathrm{a}, \mathrm{b}, \mathrm{c})^{*}$} \\
\hline & Severe: Mean \pm SD & $71.8 \pm 4$ & & \\
\hline & Profound: Mean \pm SD & $91 \pm 4.2$ & & \\
\hline \multirow[t]{3}{*}{$\begin{array}{l}\text { SRSs }[\% \\
\text { correct }]\end{array}$} & $\begin{array}{l}\text { Moderately severe: Mean } \pm \\
\text { SD }\end{array}$ & $65.7 \pm 8.7$ & \multirow[t]{3}{*}{$37.3^{\diamond}$} & \multirow[t]{3}{*}{$0.000(\mathrm{a}, \mathrm{b}, \mathrm{c})^{*}$} \\
\hline & Severe: Mean \pm SD & $51.3 \pm 11$ & & \\
\hline & Profound: Mean \pm SD & $24 \pm 6.3$ & & \\
\hline \multirow{3}{*}{$\begin{array}{l}\text { Aided } \\
\text { SRSs } \quad[\% \\
\text { correct] }\end{array}$} & $\begin{array}{l}\text { Moderately severe: Mean } \pm \\
\text { SD }\end{array}$ & $69.1 \pm 8.1$ & \multirow[t]{3}{*}{$43.5^{\diamond}$} & \multirow[t]{3}{*}{$0.000(\mathrm{a}, \mathrm{b}, \mathrm{c})^{*}$} \\
\hline & Severe: Mean \pm SD & $53.8 \pm 10.6$ & & \\
\hline & Profound: Mean \pm SD & $26.4 \pm 6.1$ & & \\
\hline
\end{tabular}

${ }^{\#} \mathrm{X}^{2}$ value; ${ }^{\diamond} \mathrm{F}$ value; ${ }^{*} \mathrm{LSD}$. 
Figure 1: Frequency of causes of HA rejection in rural geriatrics.

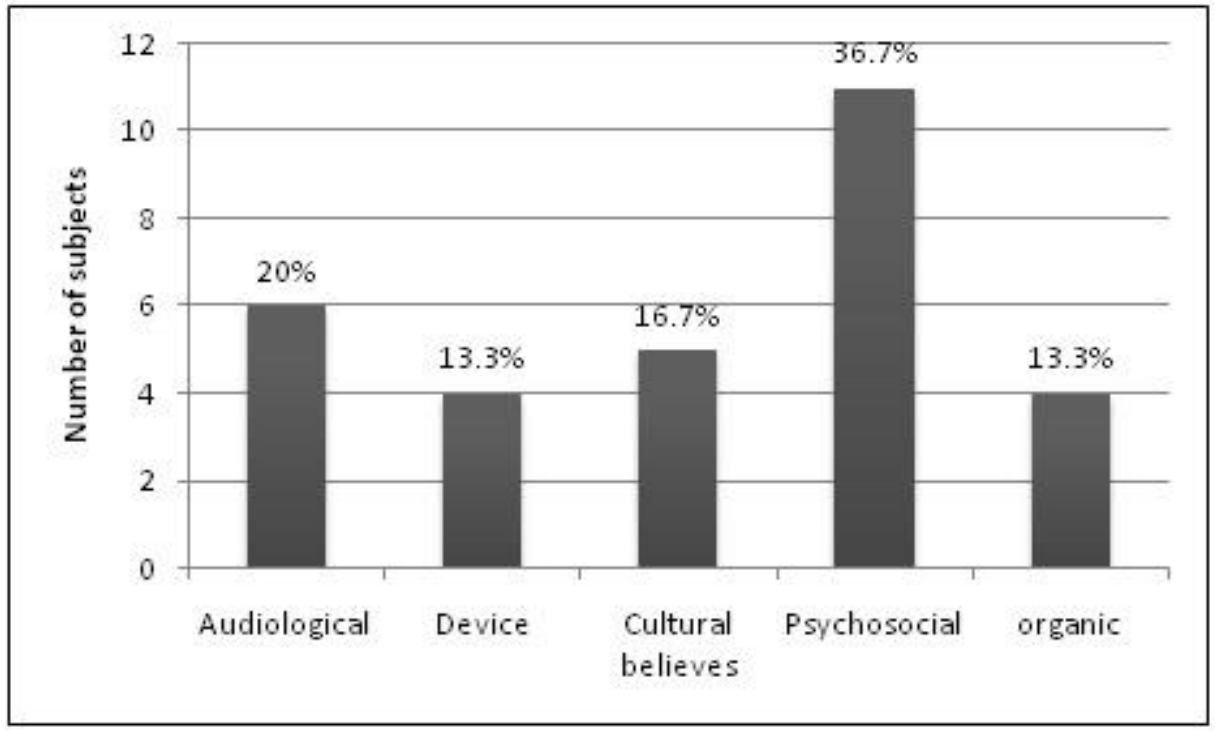

Table 3: Relationship between the demographic and audiologic characteristics and causes of HA rejection.

\begin{tabular}{|c|c|c|c|c|c|c|c|c|}
\hline \multirow{2}{*}{\multicolumn{2}{|c|}{ Characteristics }} & \multirow{2}{*}{\multicolumn{5}{|c|}{ Causes of HA rejection }} & \multirow{2}{*}{$\begin{array}{l}\text { Value } \\
1.526^{\diamond}\end{array}$} & \multirow{2}{*}{$\begin{array}{l}p \\
0.225\end{array}$} \\
\hline & & & & & & & & \\
\hline $\begin{array}{l}\text { Age } \\
\text { (years) }\end{array}$ & Mean \pm SD & $\begin{array}{l}\text { Audiologica } \\
1 \\
77.5 \pm 7^{*}\end{array}$ & $\begin{array}{l}\text { Device } \\
68.8 \pm 3.1 \\
*\end{array}$ & $\begin{array}{l}\begin{array}{l}\text { Cultural } \\
\text { believes }\end{array} \\
71.8 \pm 4.5\end{array}$ & $\begin{array}{l}\text { psychosocia } \\
1 \\
71.9 \pm 6.5\end{array}$ & $\begin{array}{l}\text { Organic } \\
73.3 \pm 5.4\end{array}$ & & \\
\hline \multirow{2}{*}{$\begin{array}{l}\text { Gender: } \\
\operatorname{no}(\%)\end{array}$} & Male & $4(23.5 \%)$ & $2(11.8 \%)$ & $2(11.8 \%)$ & $8(47.1 \%)$ & $1(5.9 \%)$ & \multirow[t]{2}{*}{$3.671^{\#}$} & \multirow[t]{2}{*}{0.452} \\
\hline & Female & $2(11.8 \%)$ & $2(11.8 \%)$ & $3(23.1 \%)$ & $3(23.1 \%)$ & $3(23.1 \%)$ & & \\
\hline \multirow{2}{*}{$\begin{array}{l}\text { Education } \\
\text { no(\%) }\end{array}$} & Educated & $7(38.9 \%)^{*}$ & $2(11.1 \%)$ & $1(5.6 \%)^{*}$ & $5(27.8 \%)$ & $3(16.7 \%)$ & \multirow[t]{2}{*}{$9.977^{\#}$} & \multirow[t]{2}{*}{0.041} \\
\hline & Illiterate & $0(0 \%)^{*}$ & $2(16.7 \%)$ & $\begin{array}{l}5(41.7 \%) \\
*\end{array}$ & $4(13.3 \%)$ & $1(8.3 \%)$ & & \\
\hline \multirow[t]{2}{*}{$\begin{array}{l}\text { HHIE-S: } \\
\text { no(\%) }\end{array}$} & $\begin{array}{l}\text { Non- } \\
\text { handicapped } \\
(\leq 8)\end{array}$ & $0(0 \%)^{*}$ & $3(21.4 \%)$ & $1(7.1 \%)$ & $6(42.9 \%)$ & $\begin{array}{l}4(28.6 \%) \\
*\end{array}$ & \multirow[t]{2}{*}{$12.8^{\#}$} & \multirow[t]{2}{*}{0.012} \\
\hline & $\begin{array}{l}\text { Handicappe } \\
\mathrm{d}(>8)\end{array}$ & $6(37.5 \%)^{*}$ & $1(6.3 \%)$ & $4(25 \%)$ & $5(16.7 \%)$ & $0(0 \%)^{*}$ & & \\
\hline \multirow{3}{*}{$\begin{array}{l}\text { Frequenc } \\
\mathrm{y} \text { of HL } \\
\text { degrees: } \\
\text { no }(\%)\end{array}$} & $\begin{array}{l}\text { Moderately } \\
\text { severe }\end{array}$ & $1(7.1 \%)^{*}$ & $3(21.4 \%)$ & $2(14.3 \%)$ & $5(35.7 \%)$ & $3(21.4 \%)$ & \multirow[t]{3}{*}{ \# 13.906} & \multirow[t]{3}{*}{0.084} \\
\hline & Severe & $2(18.2 \%)$ & $1(9.1 \%)$ & $3(27.3 \%)$ & $4(36.4 \%)$ & $1(9.1 \%)$ & & \\
\hline & Profound & $4(80 \%)^{*}$ & $0(0 \%)$ & $1(20 \%)$ & $0(0 \%)$ & $0(0 \%)$ & & \\
\hline \multirow{2}{*}{$\begin{array}{l}\text { Type of } \\
\text { HL: } \\
\text { no(\%) }\end{array}$} & SNHL & $7(31.8 \%)$ & $4(18.2 \%)$ & $5(22.7 \%)$ & $5(22.7 \%)$ & $1(4.5 \%)$ & \multirow[t]{2}{*}{$10.54^{\#}$} & \multirow[t]{2}{*}{0.032} \\
\hline & Mixed HL & $0(0 \%)$ & $0(0 \%)$ & $1(12.5)$ & $4(50 \%)$ & $\begin{array}{l}3(37.5 \%) \\
*\end{array}$ & & \\
\hline $\begin{array}{l}\text { SRS [\% } \\
\text { correct] }\end{array}$ & Mean \pm SD & $35.4 \pm 13.2$ & $56 \pm 8.6$ & $46 \pm 19.4$ & $63.6 \pm 9.9$ & $71 \pm 6.8$ & $7.357^{\diamond}$ & $\begin{array}{l}0.000 \\
(\mathrm{a}, \mathrm{b}, \mathrm{ab}, \mathrm{bc}, \mathrm{bc}) \\
*\end{array}$ \\
\hline
\end{tabular}

${ }^{\#} \mathrm{X}^{2}$ value; ${ }^{\diamond} \mathrm{F}$ value; ${ }^{*} \mathrm{LSD}$. 
Figure 2: Distribution of causes of HA rejection relative to different degrees of HL.

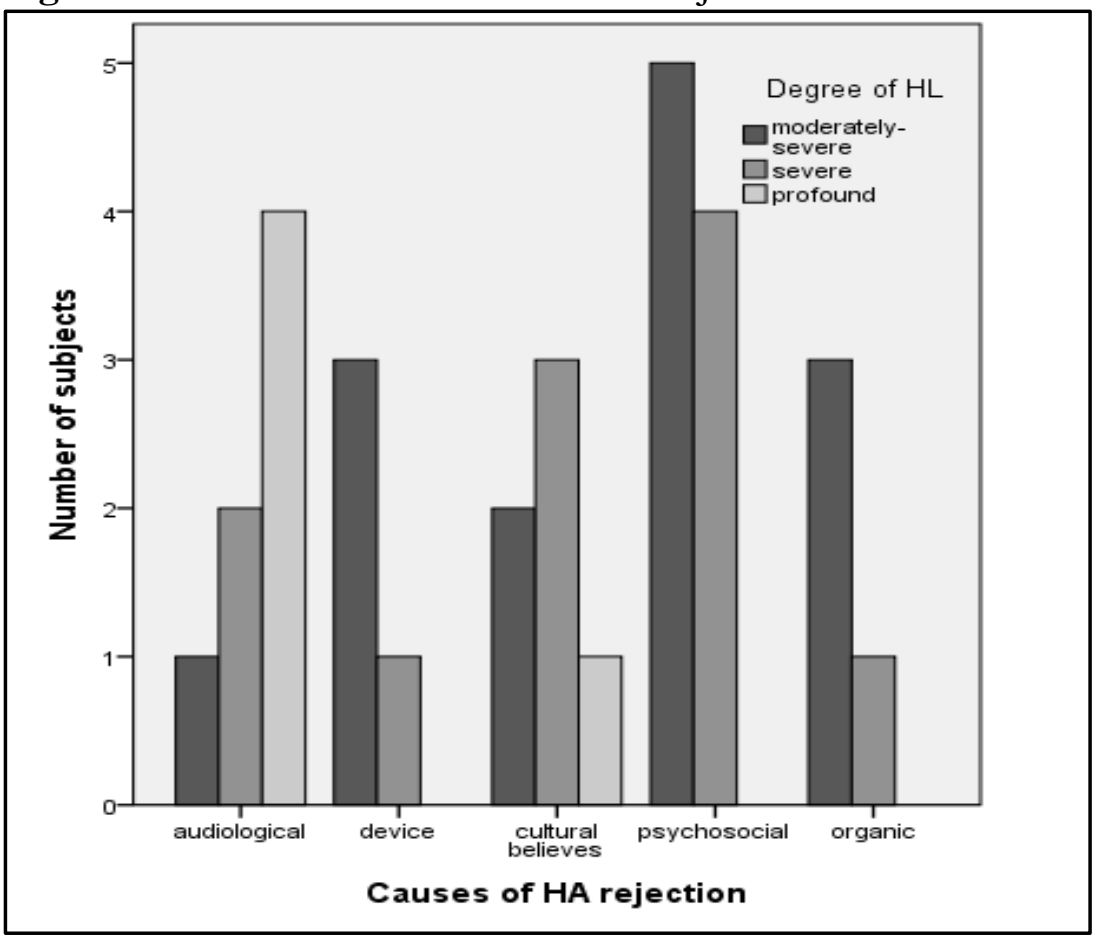

Figure 3: Distribution of causes of HA rejection relative to different types of HL.

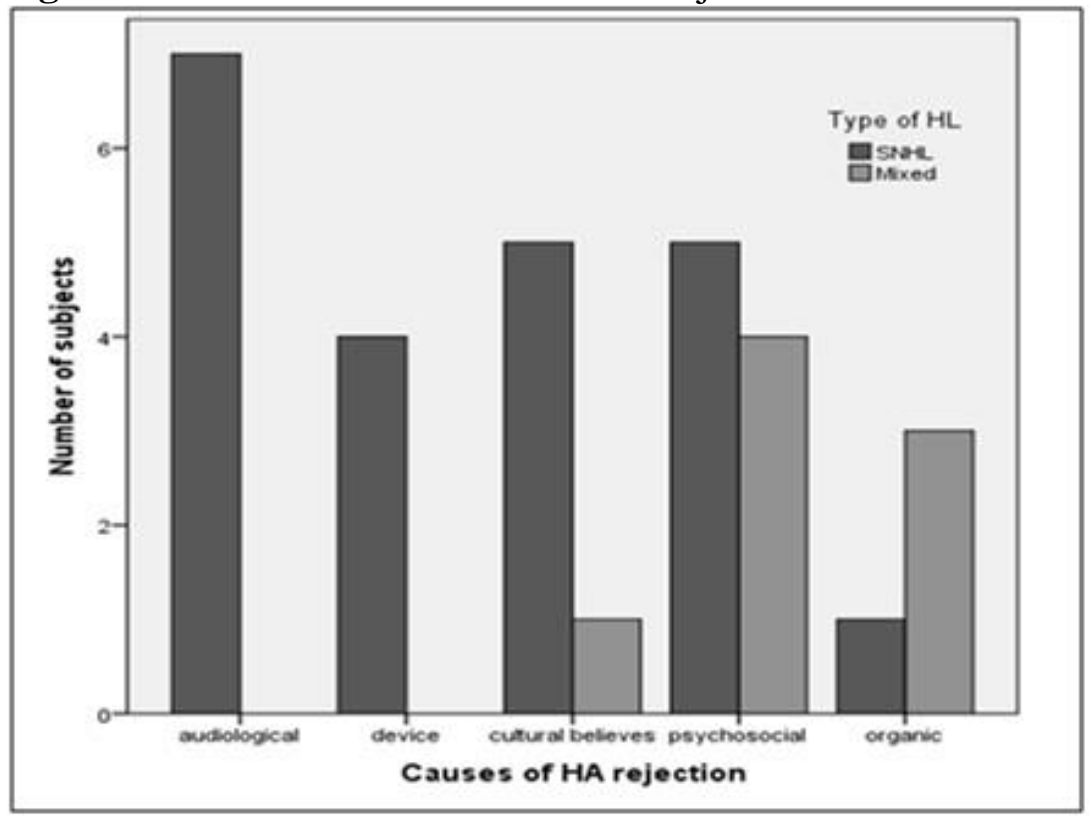

\section{DISCUSSION}

This study aimed to clarify the underlying causes of HA rejection among rural geriatric population. The main findings included groups of factors arranged from the higher to lower prevalence as follows; psychosocial (36.7\%), audiological (20\%), and cultural believes (16.7\%) followed by device $(13.3 \%)$, and organic $(13.3 \%)$ factors. The inherited way of thinking in rural areas could be the underlying cause for the more prevalent psychosocial factors. Assuming that $\mathrm{HL}$ is an evidence of disability contributes to stigma of HA use. In agreement with this finding, previous studies reported that stigma to HAs was a common cause for their rejection in older subjects ${ }^{[16,17]}$. Moreover, elders found fitting with HAs did not preserve natural hearing. They gave themselves no chance to cope with the new sound quality and became disappointed with their HAs. The thought that HAs are only useful in limited 
situations, in addition to the insistence of family to have HAs although the old subject is not convinced with HAs usefulness, are more factors.

In spite of the evolving technology, there is still a considerable rate of HA rejection in hearing impaired elders ${ }^{[5,18]}$. This study demonstrated multiple reasons for dissatisfaction with HAs including poor benefit, and discomfort. Poor benefit resulted from poor speech recognition, poor sound quality, and difficult listening with intervening noise, whereas discomfort with HA resulted from abnormal loudness growth, distortion, and internal noise. Similarly, several researchers reported reasons related to the limited HA value and comfort $[8,17,19,20]$.

In rural areas, HA rejection was tightly related to the cultural belief that HL is a natural outcome of aging process. A similar reason was also demonstrated in developing countries ${ }^{[17]}$. This idea could be related to the underestimation of hearing disability and limited knowledge about HA benefits. Furthermore, device related factors such as cost of HAs, cost of batteries, and cost and service of maintenance were important factors that also reported in literature [17,20-22]. Organic causes related to ear infection or allergy from the material of HA or ear mold were demonstrated in some cases in this study and supported by other studies ${ }^{[17,23]}$.

Predominance of different causes of HA rejection could be affected by several demographic and audiologic features of geriatric population. Age was significantly older among subjects who rejected their HAs due to audiological causes. The current and previous studies revealed that HL severity increases with age ${ }^{[1,3]}$. Profound SNHL with more severe hearing disability are common characteristics for these older age subjects. In profound HL, there was marked reduction in speech recognition in addition to uncomfortable listening due to recruitment, tinnitus, and internal noise that did not improved significantly following HA fitting. This could explain the association between older ages and audiological characteristics for HA rejection. For those who were relatively younger and had lower degrees of disability and HL, the financial issues take the upper hand.

There were no differences between males and females regarding causes of HA rejection. In literature, there was more prevalence for stigma of HA use but in younger females ${ }^{[24]}$. The effect of education revealed significant difference between educated and illiterate subjects for audiological and cultural believes. Education improves acceptance of a hearing problem, understanding of HA benefits, and access to HAs [6]. Thus, causes related to cultural believes were significantly limited among educated subjects but higher among illiterates. However, audiological causes were more prevalent for educated subjects due to factors related to severity of HL and poor benefit from HAs.

The self-perceived hearing difficulty as measured with the HHIE-S provides an idea about the degree of handicap resulting from hearing impairment. The degree of handicap is positively correlated with HA administration and satisfaction [20,25]. However, severer degrees of handicap cause poor speech intelligibility with gaining very low benefit from HAs with subsequent rejection. Therefore, in this study, the audiological causes of HA rejection was significantly related to the presence of handicap with limited benefit from HA. Cases with no perceived handicap rejected their HAs due to other causes that could be psychosocial, organic, financial, and cultural.

In the current study, causes of HA rejection differed according to the degree of HL. Lower degrees of HL exhibited more prevalence for the psychosocial, financial, and organic causes, whereas higher degrees exhibited more prevalence for the audiological causes. Moreover, SNHL revealed more prevalence for the audiological causes while the mixed HL revealed more prevalence for the organic and psychosocial causes. Severer HLs especially the SNHL associated with lower speech intelligibility even after HA fitting. Thus, the audiological causes were more prevalent in such cases that may be potential candidates for cochlear implantation. 
Small sample size and lack of the estimation of the proportion of HA rejection relative to HA possession could be the possible limitations of the present study. In future studies, larger samples including HA owners, either users or non-users, will clarify the size of HA rejection problem. Consequently, appropriate solutions could be adopted to solve this problem in rural elder population. Follow up utilities in rural areas could be framed so that the majority of geriatrics with HL and their families are educated about HA benefits to correct the wrong believes and encourage wearing HAs. Shift to another form of rehabilitation such as cochlear implantation could be needed in cases that show no benefit from HAs. Moreover, findings resources to provide financial support will help to solve the cost problem.

\section{CONCLUSION}

Hearing rehabilitation using
technology alone does not meet the requirements of hearing impaired elderly. In rural areas, HA rejection is not limited to audiological, device related, and organic causes, but mainly related to the psychosocial causes, and cultural believes. Moreover, the prevalence of these causes could be affected by age, education, self-perceived handicap, type and degree of HL, and HA benefit. Knowing the causes of HA rejection provide a good insight for the modifications needed to improve rehabilitation programs and services provided to hearing impaired geriatrics.

\section{REFERENCES}

1. WHO. WHO global estimates on prevalence of hearing loss. 2012; Available from: www.who.int/pbd/deafness/WHO_GE_HL.pdf . Accessed March 15, 2017.

2. Lin FR, Niparko JK, Ferrucci L. Hearing loss prevalence in the United States. Arch Inter Medicine 2011; 171:1851-1853.

3. Abdel-Hamid O, Khatib OM, Aly A, Morad M, Kamel S. Prevalence and patterns of hearing impairment in Egypt: a national household survey. East Mediterr Health J 2007; 13(5): 1170-1180.

4. Gopinath B, Wang JJ, Schneider J, Burlutsky G, Snowdon J. McMahon CM, Leeder SR et al. Depressive symptoms among older hearingimpaired adults: the Blue Mountains Study. J Am Geriatr Soc 2009; 57: 1306 -1308.

5. Nirmalasari O, Mamo SK, Nieman CL, Simpson A, Zimmerman J, Nowrangi MA, Lin FR et al. Agerelated hearing loss in older adults with cognitive impairment. Int Psychogeriatr 2017; 29(1): 115121.

6. Popelka MM, Cruickshanks KJ, Wiley TL, Tweed TS, Klein BE, Klein R. Low prevalence of hearing aid use among older adults with hearing loss: the epidemiology of hearing loss study. J Am Geriatr Soc 1998; 46: 1075-1078.

7. Kochkin S, Rogin CM. Quantifying the obvious: the impact of hearing instruments on quality of life. Hear Rev 2000; 7: 6-34.

8. Hartley D, Rochtchina E, Newall P, Golding M, Mitchell P. Use of hearing aids and assistive listening devices in an older Australian population. J Am Acad Audiol 2010; 21: 642-653.

9. Cox RM, Alexander GC, Gray GA. Who wants a hearing aid? Personality profiles of hearing aid seekers. Ear Hear 2005; 26: 12-26.

10. Meister H, Walger M, Brehmer D, von Wedel UC, von Wedel $\mathrm{H}$. The relationship between pre-fitting expectations and willingness to use hearing aids. Int J Audiol 2008; 47: 153-159.

11. King G, Farmer J. What older people want: evidence from a study of remote Scottish communities. Rural Remote Health 2009; 9(2): 1166.

12. Chia EM, Wang JJ, Rochtchina E, Cumming RR, Newall $P$, Mitchell P. Hearing impairment and health-related quality of life: the Blue Mountains hearing study. Ear Hear 2007; 28: 187-195.

13. Ricketts TC, Johnson-Webb KD, Taylor P. Definitions of Rural: A Handbook for Health Policy Makers and Researchers. Chapel Hill: North Carolina Rural Health Research Program, Cecil G. Sheps Center for Health Services Research, University of North Carolina, 1998, 13 p.

14. Ventry IM, Weinstein BE. Identification of elderly people with hearing problems. ASHA 1983; 23: 3742.

15. Clark JG, Uses and abuses of hearing loss classification. ASHA 1981; 23:493-500.

16. Franks JR, Beckmann NJ. Rejection of hearing aids: Attitudes of a geriatric sample. Ear Hear 1985; 6: 161-166.

17. Archana G, Krishna Y, Shiny R. Reasons for nonacceptance of hearing aid in older adults. Indian J Otol 2016; 22: 19-23.

18. Kelly TB, Tolson D, Day T, McColgan G, Kroll T, Maclaren W. Older people's views on what they need to successfully adjust to life with a hearing aid. Health Social Care Commun 2013; 21(3): 293302.

19. Bertoli S, Staehelin K, Zemp E, Schindler C, Bodmer D, Probst R. Survey on hearing-aid use and satisfaction in Switzerland and their determinants. Int J Audiol 2009; 48: 183-195.

20. Gopinath B, Schneider J, Hartley D, Teber E, McMahon CM, Leeder SR, Mitchell P. Incidence and predictors of hearing-aid use and ownership among older adults with hearing loss . Annals Epidemiol 2011; 21: 497-506.

21. CohenMansfield J, Taylor JW. Hearing aid use in nursing homes, Part II: Barriers to effective 
utilization of hearing aids. J Am Med Direct Assoc 2004; 5: 289-296.

22. Lupsakko TA, Kautiainen HJ, Sulkava R. The nonuse of hearing aids in people aged 75 years and over in the city of Kuopio in Finland. Eur Arch Otorhinolaryngol 2005; 262: 165-169.

23. Kochkin S. MarkeTrak V. Why my hearing aids are in the drawer: The consumers perspective. Hear $\mathbf{J}$ 2000; 53: 34-41.
24. Wong PW, McPherson B. Reasons for nonadoption of a hearing aid among elderly Chinese. Asian J Gerontol Geriatr 2010; 5: 62-68.

25. Knudsen LV, Oberg M, Nielsen C, Naylor G, Kramer SE. Factors influencing help seeking, hearing aid uptake, hearing aid use and satisfaction with hearing AIDS: a review of the literature. Trends Amplif. 2010; 14: 127-154. 
Appendix 1: The Arabic translated Hearing Handicap Inventory for the Elderly (version of screening).

\begin{tabular}{|c|c|c|c|}
\hline$(\cdot)$ V & 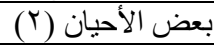 & 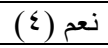 & \\
\hline & & & 1 - هل تسبب لك مشكلة السمع الشعور بالحرج عند مقابلة أشخاص جدد؟ \\
\hline & & & r - هل تتسبب للك مشكلة السمع الشعور بالإحباط عند التحدث إلى أفر اد عائلتك؟؟ \\
\hline & & & r- هل لايك صعوبة في الاستماع عندما يتحدث شخص ما بالهمس؟ \\
\hline & & & ع ـ هل تشعر ان مشكلة السمع تسبب للك اعاقة؟ \\
\hline & & & 0ـ - هل تسبب للك مشكلة السمع صعوبة عند زيارة ألصدقاء أو ألقارب أو الجيران؟ \\
\hline & & & 7- هل تسبب للك مشكلة السمع حضور أقل مما تريد للمحاضر ات أو الخدمات الدينية؟ \\
\hline & & & V- هل تسبب مشكلة السمع في وجود جدال مع أفر اد العائلة؛؟ ل \\
\hline & & & 1-ـ هل تسبب للك مشكلة السمع صعوبة عند الاستماع إلى التلفزيون أو الر اديو؟ \\
\hline & & & 9- هل تشعر أن الصعوبة في السمع تعيق حياتك الثخصية أو الاجتماعية؛ \\
\hline & & & • ( ـ هل مشكلة السمع تسبب للك صعوبة عندما تكون في مكان عام مع الأقارب أو الأصدقاء؟ \\
\hline
\end{tabular}

Appendix 2: The Arabic form of queries regarding hearing aid rejection in rural geriatric population.

\begin{tabular}{|c|c|c|}
\hline \multirow[t]{2}{*}{ - الآجابة } & الاستفسارات & العوامل - ل العل \\
\hline & تمييز الكلام & سمعية \\
\hline & 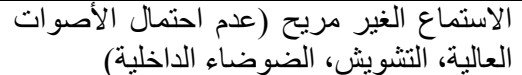 & \\
\hline & صعوبة الاستماع في وجود ضوضاء & \\
\hline & ضعف جودة الصوت & \\
\hline & التكلفة المادية & 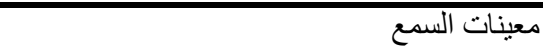 \\
\hline & مشاكل الصيانة & \\
\hline & 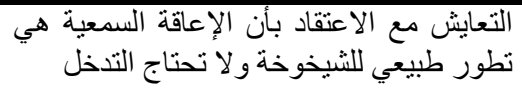 & المعتقدات الثقافية \\
\hline & الاحر اج من استخذام السماعة معينة السمع & نفسية-اجتماعية \\
\hline & 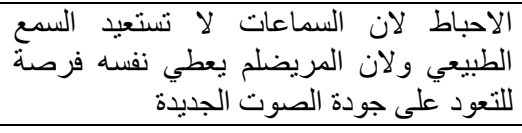 & \\
\hline & السماعة لا تفيد الا في مو اقف محدودة & \\
\hline & اصرار الأسرة على الحصول على السماعة & \\
\hline & حساسية الجلد & عضوية \\
\hline & التهاب الجلد وقناة الأذن & \\
\hline
\end{tabular}

